\title{
First record of a homolid crab (Crustacea: Decapoda: Homoloidea) from the early Eocene of the Iberian Peninsula
}

\section{Primer reporte de un cangrejo homólido (Crustacea: Decapoda: Homoloidea) del Eoceno temprano en la Península Ibérica}

Fernando A. Ferratges ${ }^{1}$, José Luis Domínguez ${ }^{2}$, Àlex Ossóo ${ }^{3, *}$

${ }^{1}$ Departamento de Ciencias de la Tierra-IUCA, Universidad de Zaragoza, E-50009, Zaragoza, Spain.

${ }^{2}$ José María Muñoz Damián, 6, bloque 1, bajo B, 50011, Zaragoza, Spain.

${ }^{3}$ Llorenç de Villalonga, 17B, 1-1, 43007 Tarragona, Catalonia. aosso@comt.cat
* Corresponding author: (A. Ossó)

\begin{abstract}
We describe a new species of homolid crab from the Ypresian (early Eocene) Roda Formation of Huesca province (Aragon, Spain). In spite of the fragmentary condition of the sole specimen, some preserved frontal elements, and in particular the complete left cheliped, allow inclusion it within the genus Paromola Wood-Mason in Wood-Mason and Alcock, 1891, based on morphological similarities with the extant species of this genus. Direct comparison with specimens of the extant Paromola cuvieri (Risso, 1815) confirms this systematic assignment. Paromola bretoni n. sp. is the first homolid reported in the Cenozoic of the Iberian Peninsula, and expands the rich decapod fossil record of the Eocene basins of southern Pyrenees.
\end{abstract}

\section{How to cite this article:}

Ferratges, F.A., Domínguez, J.L., Ossó, À., 2021, First record of a homolid crab (Crustacea: Decapoda: Homoloidea) from the early Eocene of the Iberian Peninsula: Boletín de la Sociedad Geológica Mexicana, 73 (3), A311220. http://dx.doi.org/10.18268/ BSGM2021v73n3a311220

Manuscript received: December 15, 2020

Corrected manuscript received: December 26, 2020

Manuscript accepted: December 31, 2020

Peer Reviewing under the responsability of Universidad Nacional Autónoma de México.

This is an open access article under the CC BY-NC-SA license(https://creativecommons.org/licenses/by-nc-sa/4.0/)
Keywords:Systematics, Brachyura, Homolidae, Ypresian, Pyrenees.

\section{RESUMEN}

Se describe una nueva especie de cangrejo homólido, de la Formación Roda, Ypresiano (Eoceno temprano) de la provincia de Huesca (Aragón, España). A pesar de que el único ejemplar se halla parcialmente fragmentado, la similitud morfológica con especies actuales de los elementos conservados de la región frontal y en especial el completo quelípedo izquierdo, permite ubicarlo en el género Paromola Wood-Mason WoodMason and Alcock, 1891. Comparaciones con ejemplares actuales de Paromola cuvieri (Risso, 1815) confirmarían la validez de esta ubicación sistemática. Paromola bretoni n. sp. es el primer homólido reportado en el Cenozoico de la Península Ibérica y amplia la riqueza de registros sobre decápodos fósiles del Eoceno en las cuencas Surpirenaicas.

Palabras clave: Sistemática, Bra quiura, Homolidae, Ypresiano, Pirineos. 


\section{Introduction}

Records of fossil homolids in the Eocene of Europe are not uncommon, for instance in northern Italy, where several genera and species of Homolidae De Haan, 1839 have been described (De Angeli et al., 2019, p. 20), as well as in the British Isles (Collins et al., 2020, p. 32) and Denmark (Collins et al., 2005, p. 19-20). Records of the Homolidae have never been reported to date from the Eocene of the Iberian Peninsula. Therefore, this is the first report for the family in the Eocene of the Iberian Peninsula. Here we report the first occurrence fossil homolid crabs in the Eocene of the Iberian Peninsula. The material is represented by a crab carapace fragmentarily preserved, decorticated, and preserving some cuticle remains and pereopods, recovered from early Eocene strata near the village of Roda de Isábena (Huesca province, Aragon, Spain). A proper mechanical preparation of the holotype, partially destroyed by a previous inadequate attempt of preparation, allowed us to reveal important elements, such as the complete left cheliped and partial ambulatory legs. The remains of the intralineal carapace and of the left extralineal flank, with partially preserved cuticle, and the peculiar morphology of the left cheliped, as well as the presence of the linea homolica, indicate a clear affinity with Homolidae.

Here we describe Paromola bretoni n. sp., a new fossil species of the extant genus Paromola, with only two other fossil species known: P. rosenburgensis Nyborg and Garassino, 2017, and P. vetula Crawford, 2008 (see Nyborg and Garassino, 2017).

Extant species of Paromola are spread worldwide (Guinot and Richer de Forges, 1995, fig. 70), usually inhabiting the upper bathyal zone common among homolids, albeit they can also inhabit shallower depths (ibid, p. 489-491, fig. 76), similar to the palaeoenvironment where the fossil specimen dwelt. Explanation on the former and current systematics of Homoloidea De Haan, 1839 are summarized by Guinot (2019, p. 753).

\section{Geological setting}

The Tremp-Graus Basin (southern Pyrenees) records marine sediments from the Thanetian-lower Cuisian (lower Ypresian, lower Eocene). Paleogeographically, during the Paleocene-Eocene, these basins corresponded to an elongated gulf connected to the west by the Bay of Biscay, located on the southern limit of the axial zone of the Pyrenees, in tropical latitudes (Hay et al., 1999). The Upper Palaeocene to Lower Eocene in this area consists in the following formations: Serraduy, Puebla Limestone, Roda, Morillo and San Esteban (Figure 1); and it is bounded by unconformities related to tectonic activity (Leren et al., 2010).

The studied material comes from the exposed outcrop of prodelta marls corresponding to the Roda Formation (Figure 1), located near to Roda de Isábena (northeast of Huesca, Spain). This formation exposes a thick succession of marls and sandstones and has provided an interesting decapod assemblage (e.g. Vía Boada, 1959; Vía, 1969, 1973; Artal and Castillo, 2004; Artal et al., 2005, 2013a, 2013b; Schweitzer et al., 2007; Van Bakel et al., 2012).

The Roda Formation, is coarsening and shallowing upwards (Molenaar and Martinius, 1990), and show a general progradational pattern to the S and SW (Puigdefàbregas et al., 1985; Molenaar et al., 1988; Lopez-Blanco et al., 1991, 2003; Nio and Yang, 1991; Lopez-Blanco, 1996; Molenaar and Martinius, 1996; Leren et al., 2010).

This formation has been biostratigraphically dated as lower Ypresian in age (Samsó et al., 1990; Tosquella et al., 1990) and consists of a succession of up to $200 \mathrm{~m}$ thick formed of shallow-marine, mixed siliciclastic-carbonate deposits (Martinius and Molenaar, 1991).

Abbreviations. MPZ: Museo de Ciencias Naturales de la Universidad de Zaragoza (Spain). ICMD: Institut de Ciències del Mar (ICM-CSIC), Barcelona (Spain). 


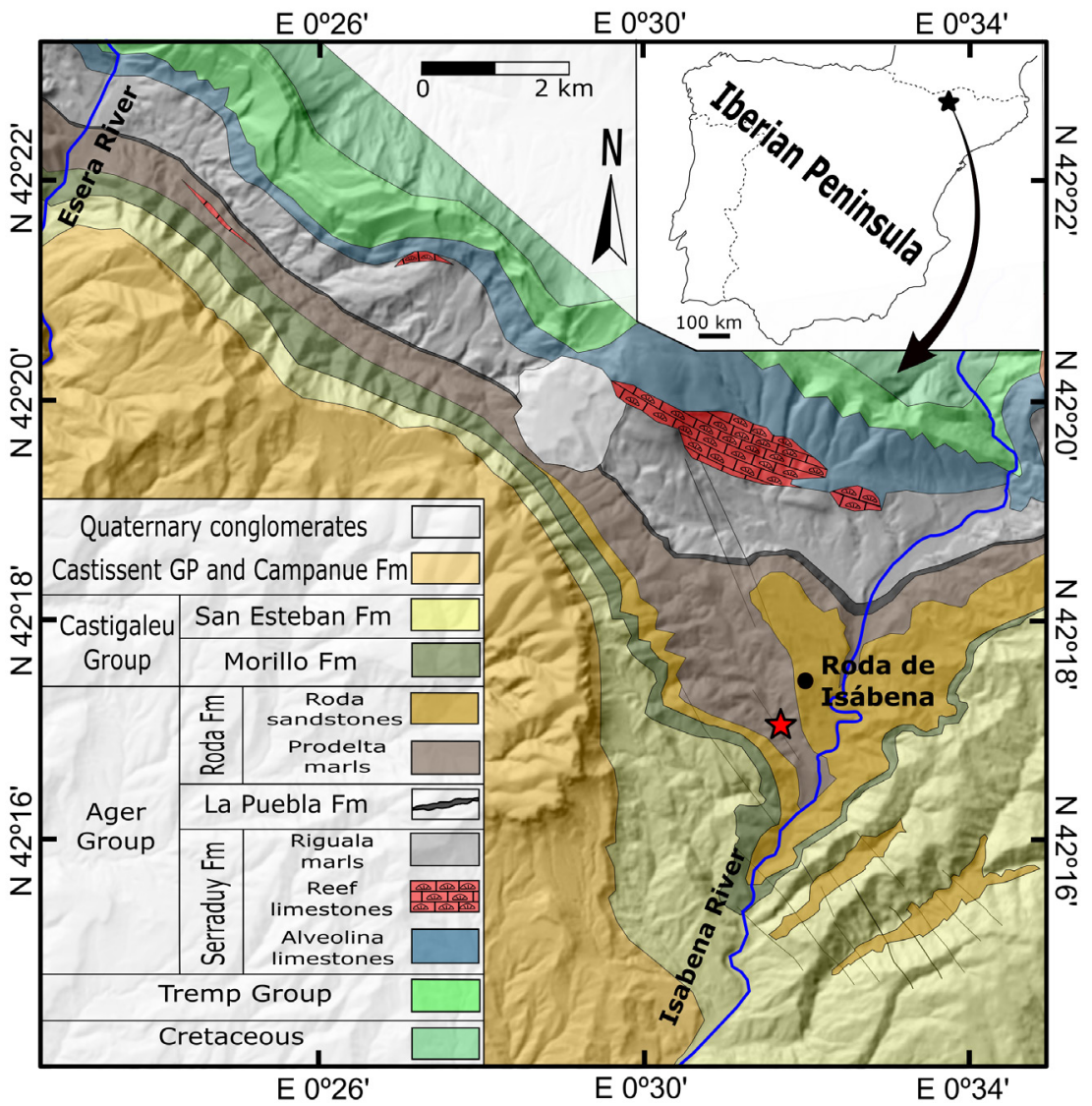

Figure 1 Map location and explanation of formations. Red star indicates outcrop where Paromola bretoni n. sp. was recovered.

\section{Systematic palaeontology}

Infraorder Brachyura Linnaeus, 1758

Section Homoloida Karasawa, Schweitzer and 2011

Feldmann, 2011

Superfamily Homoloidea De Haan, 1839

Family Homolidae De Haan, 1839

Genus Paromola Wood-Mason in Wood-Mason and Alcock, 1891

Type species. Dorippe cuvieri Risso, 1815, by original designation.

Species. Paromola bathyalis Guinot and Richer de Forges, 1995 (extant); P. crosnieri Guinot and Richer de Forges, 1995 (extant); P. cuvieri (Risso, 1815) (extant); P. japonica Parisi, 1915 (extant); P. macrochira Sakai, 1961 (extant); P. rathbunae Porter, 1908 (extant); P. roseburgensis Nyborg and Garassino, 2017 (fossil); P. vetula Crawford, 2008 (fossil).
Paromola bretoni $\mathrm{n}$. sp

urn:Isid:zoobank.org:act:D020CE6C-4633-47 129C38-6237E281CA04

(Figures 2 and 3)

Diagnosis. Dorsal carapace longitudinally subrectangular; regions fairly defined, marked by shallow incised grooves, some culminated by upward directed spines at anterior third of carapace; widest at level of the mesobranchial region, narrowing in anterior third. Long, pointed, and moderately upturned rostrum; pseudorostral spines directed upwards, originating just above upper margin orbits. Posterior margin concave axially with two lateral reentrants. Cheliped extremely long, subcircular in section, spiny; carpus very elongated; ambulatory legs long, spiny, subcircular in section.

Etymology. Honoring the late Gérard Breton, French palaeocarcinologist. 


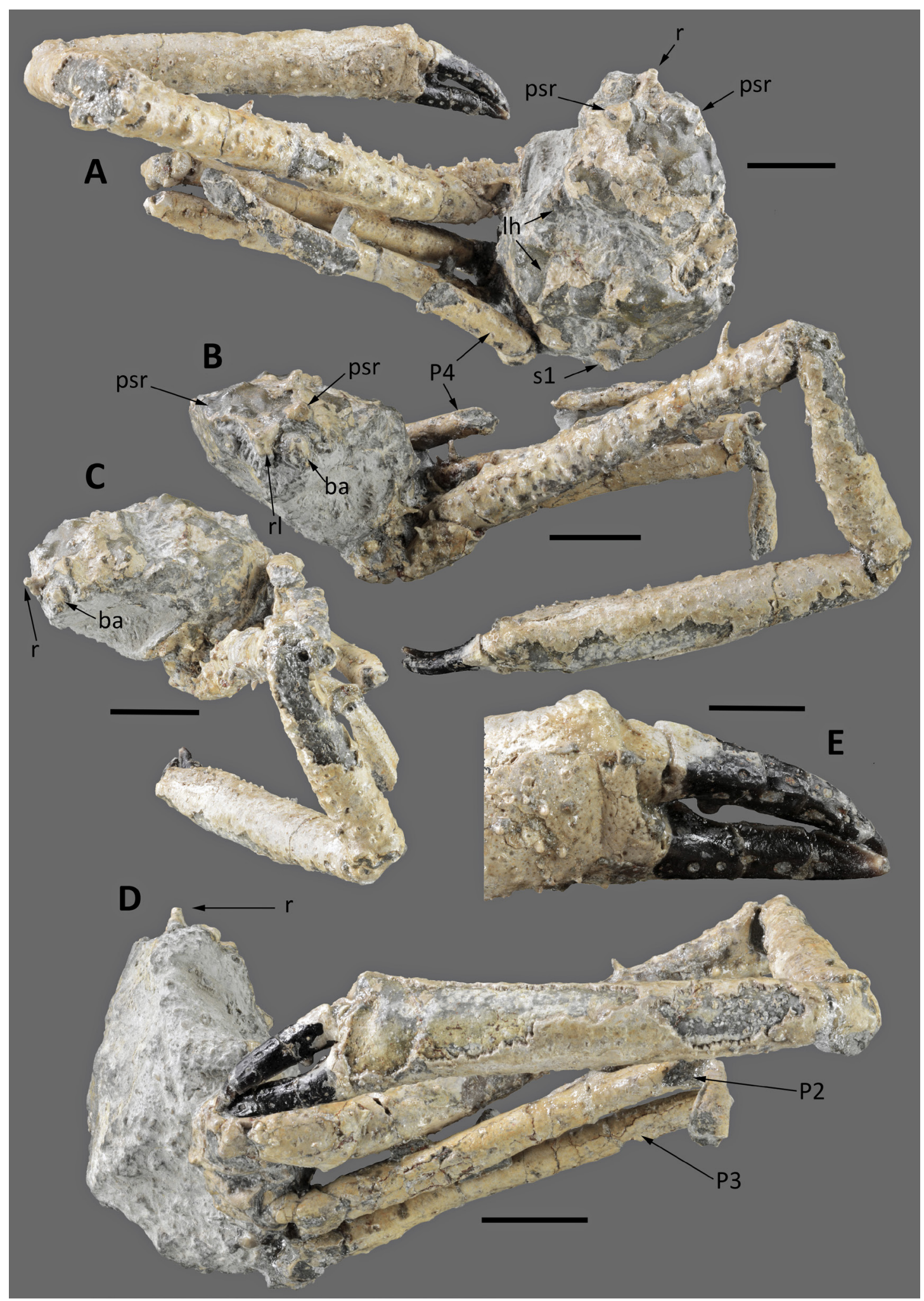

Figure 2 Paromola bretoni n. sp., holotype MPZ 2020/615. A) dorsal view; B) frontal view; C) left lateral view; D) ventral view; E) closeup of dactyli. Abbreviations: $b a=$ possibly antennular basal article; $I h=$ linea homolica; $p s r=$ pseudorostral spines; $P 2-P 4=$ ambulatory legs; $r=$ rostrum; $r l=$ rostral lobe; $s 1=$ pleonal somite 1 . Photographs by Isabel Pérez Urresti. Scale bar A, B, C, D, equal to $10 \mathrm{~mm}$; E, equal to $5 \mathrm{~mm}$. (Photographs by Isabel Pérez Urresti). 


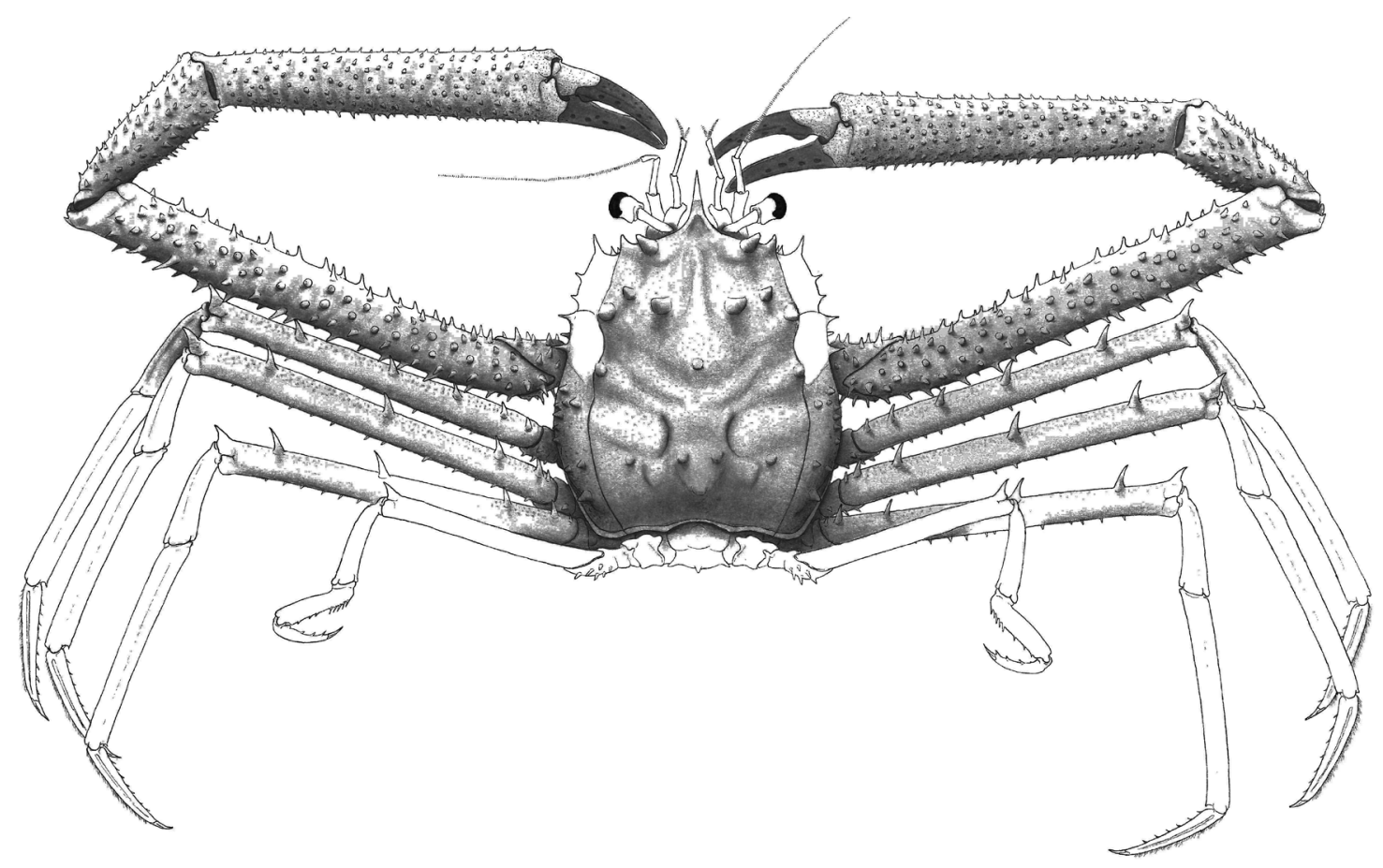

Figure 3 Idealized reconstruction of Paromola bretoni n. sp., the shaded parts taken from the specimen, and light parts taken from extant Paromola spp. (without scale).

Material. Holotype MPZ 2020/615, decorticated crab carapace preserving few remains of cuticle, and complete left cheliped and remains of left ambulatory legs.

Extant comparative examined material. Fourteen samples of Paromola cuvieri from the Biological Reference Collections (CBR) at the Institut de CiènciesdelMar(ICM-CSIC, Barcelona, Spain)(see Guerrero et al., 2020), under the catalog/accession number: ICMD002504, female, juvenile, Namibia; ICMD002505, male, Namibia; ICMD002502, male, juvenile, Barcelona; ICMD002023, female, Catalonia; ICMD119/1998, female, Namibia; ICMD002499, female, Namibia; ICMD002498, male, juvenile, Namibia; ICMD002501, male, juvenile, Namibia; ICMD002500, male, juvenile, Namibia; ICMD002503-1, male, juvenile, Namibia; ICMD002503-2, female, juvenile, Namibia; ICMD120/1998, male, juvenile, Catalonia; ICMD121/1998, male, juvenile, Catalonia; ICMD122/1998, male, juvenile, Catalonia.

Locality Type. Roda de Isábena, Huesca, Spain. Stratigraphic position and age. Roda Formation, late Ypresian, early Eocene.
Measurements. Holotype MPZ 2020/615. Carapace length $=36.05 \mathrm{~mm}$ : carapace width: $35.44 \mathrm{~mm}$ (without lateral spines; half carapace $17.72 \mathrm{~mm} \times 2$ ). Left cheliped (P1): merus = $52.39 \mathrm{~mm} \times 6.17 \mathrm{~mm}$; carpus $=27.72 \mathrm{~mm} \times 6.7 \mathrm{~mm}$; chela $=59.52 \times 10.16 \mathrm{~mm}$ (propodus + dactyli).

Description. Carapace longer than wide, subrectangular, longitudinally ovate in outline; widest at metabranchial region, narrowing in anterior third; fairly defined carapace regions; remains of cuticle of dorsal surface thin, appears gently granulate smooth, bearing presumably large upward directed acute spines (scars). Convex lateral margins of dorsal carapace, weakly vaulted longitudinally and weakly vaulted transversely in intralineal areas. Rostrum simple, pointed, rounded in section, presumably well developed and moderately upturned, rostral lobe axially sulcate; pseudorostral spines present on anterior margin, directed upward. Orbital cavity rounded, upper margin rimmed.

Anterolateral margin not preserved. Posterolateral margin convex, with at least two laterally-projecting spines. Posterior margin rimmed, consisting 
of three concave arcs, almost equal in length: one axial, and two lateral. Gastric regions not well defined, Epigastric region with two anterior swellings. Protogastric region with four transversely aligned spines (broken). Urogastric region poorly defined, weakly depressed. Cardiac region sub-triangular, with three swellings, two anterior separated by a shallow depression, and one posterior. Intestinal region poorly defined, depressed. Mesobranchial regions positioned on either side of urogastric region, weakly inflated, with at least one small spine (broken); metabranchial regions weakly inflated, with at least two small spines (broken).

Cervical groove pronounced, directed to the flanks of the carapace. Branchiocardiac groove shallow, interrupted medially. Linea homolica sinuous. Left cheliped extremely long, subcircular in section; merus strongly spinose; carpus very elongated, both, carpus and propodus, covered with small spines. Dactyli subequal, dark colored, with several setal pits; dactylus with one proximal tooth in occlusal margin; polex edentulous. Meri of P2 to $\mathrm{P} 4$, very elongated, with three to six large spines in the upper margin, and small spines in evenly spaced linear arrangement along the whole length of the lower margin.

\section{Discussion}

Although the studied specimen is partially preserved, some diagnostic characters, such as the well-preserved and extremely long left cheliped, the pointed simple rostrum, the pseudorostral spines, and the linea homolica, allow to assign it within the Homolidae with confidence.

The combination of these characters is similar to that of Paromola, and fits perfectly with the diagnosis for the genus provided by Guinot and Richer de Forges (1995, p. 358-359), in particular the acute simple rostrum, developed pseudorostral spines, and the long carpus of an extremely long cheliped. Although some other homolids also possess a simple rostrum and long chelipeds, they differ substantially from the studied specimen. For instance, some species of Homola Leach, 1816, possess acute rostrum, and long chelipeds, but they are shorter than in the new species (see Guinot and Richer de Forges, 1995, p. 335-338, fig. $11 \mathrm{a}-\mathrm{b})$. As well, species of Moloha Barnard, 1947, possess long pseudorostral spines, and dorsal carapace with long and sharp spines, which are absent or not preserved in the studied specimen (see Guinot and Richer de Forges, 1995, p. 376-391, figs. 28-33). Dagnaunus pritchardi (Jenkins, 1977), from the early Oligocene of South Australia, formerly described as Paromola pritchardi, and subsequently transferred to the former genus by Schweitzer et al. (2004, p. 134), has longer pseudorostral spines than P. bretoni n. sp. (see Jenkins, 1977).

Based upon the above mentioned characters, and the relatively large size, the placement of that specimen within Paromola, seems appropriate until new material confirms the systematic position.

The state of preservation of the carapace of Paromola bretoni n. sp., precludes us to compare it further with the fossil species above indicated. Extant species of Paromola possess a thin carapace (P. Abelló, pers. comm.), so it can be inferred that the fossil species had the same fragile cuticle, as the studied specimen, which does not help to preserve the entire carapace. However, P. bretoni $\mathrm{n}$. sp. differs from $P$. roseburgensis from the early Eocene of Oregon (USA) in having larger size, apparently shorter pseudorostral spines, and different shape of cheliped, which is shorter in P. roseburgensis (see Nyborg and Garassino, 2017, p. 140-142, figs. 3, 4). Moreover, Paromola bretoni n. sp. differs from $P$. vetula, from the Oligocene of Río Negro (Argentina) by its larger size, and its remains of dorsal carapace preserved are less granulated than in $P$. vetula (see Crawford, 2008). Londinimola williamsi Collins and Saward, 2006, from the lower Eocene of Essex (UK), draws attention by its size, and rostral and pseudorostral features, both similar to those of Paromola bretoni n. sp. Apparently, Londinimola williamsi is the closest fossil species to our species, by sharing a simple rostrum, pseudorostral spines above upper orbital margin, dorsal regions fairly defined, some culminated by upward directed spines, and linea homolica well defined, 
but it differs from Paromola bretoni $\mathrm{n}$. sp. in having a downturned rostrum instead of upturned; as well, the preserved cheliped and remains of ambulatory legs of P. bretoni $\mathrm{n}$. sp. are clearly longer and robust than in $L$. williamsi. In any case, the poor preservation of the new species, does not permit a more detailed comparison (see Collins and Saward, 2006, p. 69-70, pl. 1, figs. 1a-c, 2a, 2b).

Similarly, comparing $P$. bretoni $\mathrm{n}$. sp. with the extant species of the genus Paromola is difficult. However, despite the crushed carapace of Paromola bretoni $\mathrm{n}$. sp. could disguise the true length of it, none of those extant species seem to have such left cheliped span with respect to the carapace length. In this sense, examination and measurements of the extant specimens of $P$. cuvieri above listed, show different ratios than $P$. bretoni n. sp., for instance the carapace length-merus $\mathrm{P} 1$ length ratio is 0.600 , whereas in P. bretoni $\mathrm{n}$. sp. that ratio is 0.688 , which means that the new species has longer left cheliped with respect to the carapace size than extant $P$. cuvieri, which would favour the specific differentiation between them. Other comparative measurements regarding the carpus of $P$. bretoni $\mathrm{n}$. sp., such as carpus length-merus and length-ratio, do not show substantial differences: 0.505 in $P$. cuvieri vs. 0.529 in P. bretoni n. sp. In any case, the temporal span separating $P$. bretoni $\mathrm{n}$. sp. from the extant species, justify the erection of a new species for the Aragonese specimen.

\section{Acknowledgements}

We are grateful to Pere Abelló and Ricardo Santos-Bethencourt (ICM-CSIC, Barcelona) for providing useful comments and relevant data, to Isabel Pérez Urresti, for her help in photographing the sample. We also thank Alessandro Garassino (Loma Linda University, CA, USA) and Francisco Vega (UNAM, Mexico) by their reviews that improved the original manuscript. Javier Luque helped us with the English language and provided useful comments. The research of FAF is supported by projects CGL2017-85038-P subsidized by the Spanish Ministry of Science and Innovation, the European Regional Development Fund, FPU Grant (Spanish Ministry of Science and Innovation), and Project E18 Aragosaurus: Recursos Geológicos y Paleoambientes of the government of Aragón-FEDER.

\section{References}

Artal, P., Castillo, J., 2004, Periacanthus ramosus (Crustacea, Decapoda), nueva especie del Eoceno inferior de Huesca (Aragón, España): Batalleria, 12, 39-44.

Artal, P., Ossó, A., Domínguez, J.L., 2013a, Archaeoportunus isabenensis, a new genus and species of portunoid crab (Crustacea, Decapoda) from the lower Eocene of Huesca (Spain): Boletín de la Sociedad Geológica Mexicana, 65(2), 307-317. https://doi. org/10.18268/bsgm2013v65n2a12

Artal, P., van Bakel, B.W.M., Castillo, J., 2005, Retropluma Gill, 1894 (Crustacea, Decapoda) from the Eocene of the eastern Pyrenees (Spain, France): Cainozoic Research, 5(1-2), 63-69.

Artal, P., van Bakel, B.W.M., Fraaije, R.H.B., Jagt, J.W.M., 2013b, New retroplumid crabs (Crustacea, Brachyura, Retroplumidae Gill, 1894) from the Eocene of Huesca (Aragón, Spain): Zootaxa, 3652(3), 343-352. https:// doi.org/10.11646/zootaxa.3652.3.3

Barnard, K. H., 1947, Description of new species of South African Decapod Crustacea, with notes on synonymy and new records: Annals and Magazine of Natural History, 13(102), 361-392. https://doi. org/10.1080/00222934608654562

Collins, J.S.H., Mellish, G.J.T., Ross, A.J., Crabb, P.R., Donovan, S.K., 2020, A guide to the fossil Decapoda (Crustacea: Axiidea, Anomura, Brachyura) of the British Isles: Proceedings of the Geologists' Association, 131, 19-50. https://doi.org/10.1016/j. pgeola.2019.10.001 
Collins,J.S.H., Saward,J., 2006, Three new genera and species of crabs from the Lower Eocene London Clay of Essex, England: Bulletin of the Mizunami Fossil Museum, 33, 67-76.

Collins, J.S.H, Schulz, B.P., Jakobsen, S.L., 2005, First record of brachyuran decapods (Crustacea, Decapoda) from Fur Formation (early Eocene) of Mors and Fur Island, Denmark: Bulletin of the Mizunami Fossil Museum, 32, 17-22.

Crawford, R.S., 2008, A new species of fossil homolid crab (Decapoda: Brachyura) from the Río Foyel Formation (Paleogene), Río Negro Province, Argentina: Journal of Paleontology, 82(4), 835-841. https://doi. org/10.1666/06-111.1

De Angeli, A., Garassino, A., Pasini, G., 2019, Catalog and bibliography of fossil Stomatopoda and Decapoda from Italy (2007-2018): Memorie della Società italiana di Scienze naturali e del Museo civico di Storia naturale di Milano, 45, 1-86.

Guerrero, E., Abelló, P., Lombarte, A., Villanueva, R., Ramón, M., Sabatés, A., Santos, R., 2020, Biological Reference Collections ICMCSIC. versión 1.28. Institute of Marine Sciences (ICM-CSIC). Occurrence dataset. https://doi.org/10.15470/qlqqdx

Guinot, D., 2019, New hypotheses concerning the earliest brachyurans (Crustacea, Decapoda, Brachyura): Geodiversitas, 41(1), 747-796. https://doi.org/10.5252/ geodiversitas2019v41a22karasawa

Guinot, D., Richer de Forges, B., 1995, Crustacea Decapoda Brachyura: Révision de la famille des Homolidae de Haan, 1839, in Crosnier A. (ed.), Résultats des campagnes MUSORSTOM 13: Mémoires du Muséum national d'Histoire naturelle, Zoologie, 163, 283-517.

Haan, W. De, 1833-1849, Crustacea, in de Siebold, P.F. (ed.), Fauna Japonica sive Descriptio Animalium, quae in Itinere per Japoniam, Jussu et Auspiciis Superiorum, qui Summum in India Batava
Imperium tenent, suscepto, Annis 18231830 collegit, Notis, Observationibus et Adumbrationibus illustravit, XVII, XXXI: J. Muller, Amsterdam, 109-164. https://doi. org/10.5962/bhl.title. 124951

Hay, W.W., De Conto, R., Wold, G.N., Wilson, K.M., Voigt, S., Schulz, M., Wold-Rossby, A., Dullo, W.C., Ronov, A.B., Balukhovsky, A.N., Soeding, E., 1999, Alternative global Cretaceous paleogeography, in Barrera, E. and Johnson, C. (Eds.), The evolution of Cretaceous ocean/climate systems: Geological Society of America, Special Papers, 332, 1-47.

Jenkins, R.J.F., 1977, A new fossil homolid crab (Decapoda, Brachyura), Middle Tertiary, southeastern Australia: Transactions of the Royal Society of South Australia, 101, 1-10.

Karasawa, H., Schweitzer, C.E., Feldmann, R.M., 2011, Phylogenetic analysis and revised classification of podotrematous Brachyura (Decapoda) including extinct and extant species: Journal of Crustacean Biology, 31(3), 523-565. https://doi. org/10.1651/10-3423.1

Leach, W.E., 1816, A tabular view of the external characters of four classes of animal which Linne arranged under Insecta: with the distribution of the genera composing three of these classes into orders and c. and descriptions of several new genera and species: Transactions of the Linnean Society of London, 11(2), 306-400. https://doi. org/10.5962/bhl.title. 119762

Leren, B.L.S., Howel, J., Enge, H., Martinius, A.W., 2010, Controls on stratigraphic architecture in contemporaneous delta systems from the Eocene Roda Sandstone, Tremp-Graus Basin, northern Spain: Sedimentary Geology, 229, 9-40. https:// doi.org/10.1016/j.sedgeo.2010.03.013

Lopez-Blanco, M., 1996, Estratigrafía Secuencial de Sistemas Deltaicos en Cuencas de Antepais: Ejemplos de Sant Llorenç del Munt, Montserrat y Roda (Paleógeno, Cuenca de 
Antepais Surpirenaica). Unpublished Ph. D. thesis, Universitat de Barcelona, 238 p.

Lopez-Blanco, M., Chassard, A., Marzo Carpio, M., Santaeularia Solans, T., 1991. Estratigrafía y sedimentología de la Arenisca de Roda (Cuenca de Graus-Tremp, NW de Espana), in I congreso del Grupo Español del Terciario. Universitat de Barcelona, Vich, Spain, 186-189.

Lopez-Blanco, M., Marzo, M., Munoz, J.A., 2003, Low-amplitude, synsedimentary folding of a deltaic complex: Roda Sandstone (lower Eocene), South-Pyrenean Foreland Basin: Basin Research, 15, 73-95. https://doi. org/10.1046/j.1365-2117.2003.00193.x

Linnaeus, G., Von, 1758, Systema Naturae per Regna tria Naturae, secundum classes, ordines, genera, species, cum characteribus, differentiis, synonymis, locis (ed. 10), 1, 1-824, (Laurentii Salvii, Holmiae [=Stockholm]). https://doi.org/10.5962/bhl.title.156772

Martinius, A.W., Molenaar, N., 1991, A coralmollusc (Goniaraea-Crassatella) dominated hardground community in a siliciclasticcarbonate sandstone (the Lower Eocene Roda Formation, southern Pyrenees, Spain): Palaios, 6(2), 142-155. https://doi. org/10.2307/3514879

Molenaar, N., Martinius, A.W., 1990, Origin of nodules in mixed siliciclasticcarbonate sandstones, the Lower Eocene Roda Sandstone Member, southern Pyrenees, Spain: Sedimentary Geology, 66(3-4), 277-293. https://doi. org/10.1016/0037-0738(90)90064-z

Molenaar, N., Martinius, A.W., 1996, Fossiliferous intervals and sequence boundaries in shallow marine, fan-deltaic deposits (Early Eocene, southern Pyrenees, Spain): Palaeogeography, Palaeoclimatology, Palaeoecology, 121(3-4), 147-168. https:// doi.org/10.1016/0031-0182(95)00073-9

Molenaar, N., van de Bilt, E.R., van den Hoek, O., Nio, S.D., 1988, Early diagenetic alternation of shallow-marine mixed sandstones: an example from the Lower
Eocene Roda Sandstone Member, Tremp-Graus Basin, Spain: Sedimentary Geology, 55, 295-318. https://doi. org/10.1016/0037-0738(88)90136-4

Nio, S.D., Yang, C.S., 1991, Sea-level fluctuations and the geometric variability of tidedominated sand bodies: Sedimentary Geology, 70, 161-193. https://doi. org/10.1016/0037-0738(91)90140-9

Nyborg, T., Garassino, A., 2017, New Occurrences of Fossil Homolidae from the Eastern Pacific: Boletín de la Sociedad Geológica Mexicana, 69(1), 135-148. https://doi.org/10.18268/ bsgm2017v69n1a6

Parisi, B., 1915, I Decapodi giapponesi del Museo di Milano. II. Dromiacea: Atti della Società italiana di Scienze naturali e del Museo civico di Storia naturale in Milano, 54, 102-116. https://doi.org/10.5962/bhl.part. 17607

Puigdefàbregas, C., Samsó, J.M., Serra-Kiel, J. Tosquella, J., 1985, Facies analysis and faunal assemblages of the Roda Sandstone Formation, Eocene of the southern Pyrenees (abstract), in International Association of Sedimentologists, $6^{\text {th }}$ European Regional Meeting of Sedimentology, IAS, Lerida, Spain, Abstracts and Poster Abstracts, 639-642.

Porter, C.E., 1908, Nueva especie de la Fam. Homolidae. Materiales para la fauna carcinologica de Chile, VI: Revista Chilena de Historia Natural, 12(1-2), 86-88.

Risso, A., 1815, Histoire naturelle des Crustacés des environs de Nice: Paris, A la Librairie grecque-latine-allemande, 175 p. https:// doi.org/10.5962/bhl.title.8992

Sakai, T., 1961, New species of Japanese crabs from the collection of His Majesty The Emperor of Japan: Crustaceana, 3(2), 131-150. https:// doi.org/10.1163/156854061x00635

Samsó, J.M., Tosquella, J., Serra-Kiel, J., 1990, Los géneros Alveolina y Nummulites (Macroforaminiferos) del Ilerdiense medioCuisiense medio de la cuenca de Graus, Huesca. I: Sistematica de Alveolina: Boletín Geológico y Minero, 101(2), 219-252. 
Schweitzer, C.E., Artal, P., van Bakel, B.W.M., Jagt, J.W.M., Karasawa, H., 2007, Revision of the genus Titanocarcinus (Decapoda: Brachyura: Xanthoidea) with two new genera and one new species: Journal of Crustacean Biology, 27(2), 278-295. https:// doi.org/10.1651/s-2713.1

Schweitzer, C.E., Nyborg, T.G., Feldmann, R.M., Ross R.L.M., 2004, Homolidae De Haan, 1839 and Homolodromiidae Alcock, 1900 (Crustacea: Decapoda: Brachyura) from the Pacific Northwest of North America and a reassessment of their fossil records: Journal of Paleontology, 78(1), 133-149. https://doi. org/10.1666/0022-3360(2004)078\%3C013 3:hdhaha\%3E2.0.co;2

Tosquella, J., Samsó, J.M., Serra-Kiel, J., 1990, Los géneros Alveolina y Nummulites (Macroforaminíferos) del Ilerdiense MedioCuisiense Medio de la Cuenca de Graus, Huesca. II. Sistemática de Nummulites. Boletin Geológico y Minero, 101(3), 3-55.
Van Bakel, B.W.M., Guinot, D., Artal, P., Fraaije, R.H.B., Jagt, J.W.M., 2012, A revision of the Palaeocorystoidea and the phylogeny of raninoidian crabs (Crustacea, Decapoda, Brachyura, Podotremata): Zootaxa, 3215(1), 1-216. https://doi.org/10.11646/ zootaxa.3215.1.1

Vía, L., 1969, Crustáceos decápodos del Eoceno español: Pirineos, (91-94), 1-469.

Vía, L., 1973, Datos para el estudio de los crustáceos decápodos del Eoceno circumpirenáico:Jaca, Pirineos, $107 \mathrm{p}$.

Vía Boada, L., 1959, Decápodos fósiles del Eoceno español: Boletín del Instituto geológico y Minero de España, 70, 331-402.

Wood-Mason, J., Alcock. A., 1891, A note on the result of the last season's deep-sea dredging: natural history notes from H. M. Indian Marine Survey Steamer "Investigator", Commander, R. F. Hoskyn, R. N. Commanding, no. 21: Annals and Magazine of Natural History, 6(7), 258-272. 